\title{
DOSIS HIDROGEN PEROKSIDA (HP) TERHADAP DERAJAT KELULUSAN HIDUP IKAN MAS (Cyprinus carpio Linn)
}

\section{DOSE OF HYDROGEN PEROXIDE (HP) TO SURVIVAL RATE OF THE CRAP FISH (Cyprinus carpio Linn)}

\author{
HELENTINA MARIANCE MANULLANG \\ Fakultas Perikanan Universitas Dharmawangsa Medan, Jl. KL Yos Sudarso No. 224 Medan, Indonesia \\ `Email : manullanghelen@gmail.com
}

\begin{abstract}
Abstrak. Hidrogen Peroksida merupakan bahan kimia yang memiliki konstribusi cukup besar dalam bidang akuakultur, terutama sebagai bahan yang berguna untuk memperbaiki kualitas air dan mengurangi serangan patogen. Penelitian ini bertujuan untuk mengetahui pengaruh pemberian HP terhadap kelulusan hidup ikan mas. Penelitian ini merupakan penelitin eksperimen, dengan menggunakan 3 taraf perlakuan berbeda dan sebuah kontrol. Perlakuan melalui pemberian dosis Hidrogen Peroksida dengan Perlakuan A (0\%) sebagai kontrol; Perlakuan B $(0,1$ miligram/liter); Perlakuan C (0,2 miligram/liter); dan Perlakuan D (0,3 miligram/liter) Hasil penelitian menunjukan untuk kelulusan hidup ikan mas tertinggi yakni pada Perlakuan C $(93,33 \%)$, perlakuan B $(91,66 \%)$, Perlakuan A $(87,66 \%)$, dan Perlakuan D $(76,66 \%)$.
\end{abstract}

Keywords : Cyprinus carpio Linn, hidrogen peroksida, kelulusan hidup

\begin{abstract}
Hydrogen peroxide is a chemical that has a substantial contribution in the field of aquaculture, Especially as a useful ingredient to improve water quality and reduce pathogenic attacks. This research aims to determine the influence of HP delivery to the survival rate of carp fish. This research is an experimental study, using 3 different treatment levels and a control. Treatment through dosing of hydrogen peroxide with $\mathrm{A}$ treatment $(0 \%)$ as a control; Treatment $\mathrm{B}(0.1$ milligrams/Liter); Treatment $C(0.2$ milligrams/Liter); and treatment $D$ ( 0.3 milligrams/Liter). The results showed for the approval of survival rate of the highest crap fsh in the C treatment (93.33\%), Treatment B (91.66\%), treatment $\mathrm{A}(87.66 \%)$, and $\mathrm{D}$ treatment $(76.66 \%)$.
\end{abstract}

Keywords : Cyprinus carpio Linn, hydrogen peroxide, survival rate

\section{Pendahuluan}

Salah satu produk akuakultur yang potensial untuk terus diproduksi adalah ikan mas (Cyprinus carpio Linn). Ikan ini mempunyai prospek yang baik dan berkelanjutan karena permintaan terhadap kebutuhan protein hewani yang murah dan mudah didapat terus terbuka. Persaingan perdagangan ikan mas di pasar lokal maupun regional dirasakan semakin keras dan ketat. Saat ini benih merupakan faktor pendukung untuk keberlanjutan usaha budidaya. Pemenuhan kebutuhan benih harus sesuai kualitas dan kuantitsnya. Secara umum, pemasaran benih ikan mas harus dalam kondisi hidup dan merupakan benih yang sehat. Oleh karena itu, diperlukan penanganan khusus pascapanen sehingga produk akuakultur tersebut tetap hidup dan bermutu tinggi ketika sampai ke tangan konsumen.

Permasalahan yang sering dihadapi oleh para supplier dalam pengiriman ikan adalah tingkat kelulusan hidup (survival rate) yang rendah diantaranya disebabkan karena kualitas air yang memburuk selama pengangkutan. Berbagai bahan telah banyak digunakan untuk mengatasi tingginya tingkat kemaatian benih selama proses pengangkutan. Salah satunya adalah Hidrogen peroksida (HP) yang memiliki rumus kimia $\left(\mathrm{H}_{2} \mathrm{O}_{2}\right)$. Bahan kimia ini memiliki potensi menggantikan formalin dalam aplikasi akuakultur untuk mengontrol patogen seperti 
Ichthyophthitius multifiliis [1]. Selain itu, HP adalah sumber oksigen pada transportasi ikan hidup. Hidrogen peroksida membantu meningkatkan kalitas media air melalui penambahan oksigen di dalam media air [2]. Kematian ikan pada sistem pengangkutan umumnya disebabkan oleh tingginya kadar $\mathrm{CO}_{2}$, akumulasi amoniak, ikan terlalu aktif, infeksi bakteri, luka fisik akibat penanganan yang tidak tepat dan waktu yang cukup panjang selama diperjalanan menyebabkan ikan menjadi lemah dan sangat peka terhadap perubahan lingkungan sehingga ikan stres dan mati.

Teknologi pengangkutan ikan telah berkembang dengan baik saat ini, salah satunya teknik pengangkutan ikan dengan menggunakan Hidrogen Peroksida $\left(\mathrm{H}_{2} \mathrm{O}_{2}\right)$ yang diketahui dapat mempertahankan kelulusan hidup yang lebih tinggi selama pengangkutan. Permasalahannya adalah bagaimana pengaruhnya terhadap benih ikan mas, berapa dosis yang diperlukan agar ikan selama proses pengangkutan memiliki kelulusan hidup yang tinggi serta dalam keadaan sehat untuk dilakukan proses pembudidayaan atau pemeliharaan selanjutnya.

Berdasarkan tinjauan di atas, maka perlu untuk mengadakan penelitian tentang pengaruh pemberian Hidrogen Peroksida ((HP) terhadap kelulusan hidup benih ikan mas (Cyprinus carpio Linn) selama pengangkutan sistem tertutup.

\section{Tujuan Penelitian}

Penelitian ini bertujuan untuk:

1. Mengetahui pengaruh pemberian hidrogen peroksida terhadap kelulusan hidup benih ikan mas (Cyprinus carpio Linn) selama pengangkutan sistem tertutup.

2. Mengetahui rata-rata kelulusan hidup benih ikan mas (Cyprinus carpio Linn) dari masingmasing perlakuan dosis hidrogen peroksida selama pengangkutan sistem tertutup.

\section{Manfaat}

1. Sebagai informasi atau bahan acuan lebih lanjut berkenaan dengan kegiatan pengangkutan benih ikan mas (Cyprinus carpio Linn).

2. Bagi para usaha pembenihan (pembudidaya) diharapkan dapat dijadikan sumber pengetahuan dan menambah wawasan mengenai penggunaan hidrogen peroksida pada pengangkutan benih ikan.

\section{Bahan dan Metode}

\subsection{Waktu dan Tempat Penelitian}

Penelitian ini dilakukan pada tanggal 22 sampai dengan 24 Januari 2019 di Unit Pelaksana Teknis (UPT) Budidaya Perikanan Dinas Pertanian dan Kelautan Kota Medan yang beralamat di Jl. Bunga Ganyong, Kelurahan Baru Ladang Bambu, Kecamatan Medan Tuntungan.

\subsection{Bahan dan Alat Penelitian}

Bahan yang digunakan pada penelitian ini adalah benih ikan mas yang berukuran $3-5 \mathrm{~cm}$ sebanyak 240 ekor untuk bahan uji, hidrogen peroksida sebanyak $1,8 \mathrm{ml}$ sebagai bahan yang akan diuji dan air tawar berasal dari sumur bor yang sudah diendapkan selama 2 hari sebagai 
air media. Adapun wadah yang digunakan adalah bak ukuran $2 \mathrm{~m} \times 3 \mathrm{~m}$ sebanyak 1 unit untuk pemberokan benih ikan mas.

Sedangkan peralatan yang digunakan dalam penelitian ini adalah :

1. Kantong plastik dengan ketebalan $0,1 \mathrm{~mm}$, diameter $20 \mathrm{~cm}$, panjang $44 \mathrm{~cm}$ dan lebar 30 $\mathrm{cm}$ sebagai wadah air media

2. Gelas ukur digunakan untuk mengukur volume air

3. Gayung digunakan sebagai alat bantu untuk mengambil air

4. Tangguk kecil (seser) untuk memindahkan benih ikan mas

5. Thermometer untuk mengukur suhu

6. Ember untuk wadah benih ikan mas

7. Baskom untuk tempat stock air tawar

8. $\mathrm{pH}$ meter untuk mengukur $\mathrm{pH}$ air

9. DO meter untuk mengukur oksigen terlarut

10. Spuit (jarum suntik) untuk mengambil hidrogen peroksida

11. Sendok untuk mengaduk hidrogen peroksida dengan air tawar

12. Karet gelang untuk mengikat kantong plastik

13. Kendaraan roda empat untuk mengangkut benih ikan mas

14. Kamera untuk dokumentasi

\subsection{Hipotesis}

Hipotesis dalam penelitian ini adalah :

$\mathrm{H}_{\mathrm{o}}$ : Tidak ada pengaruh pemberian HP terhadap kelulusan hidup benih ikan mas (Cyprinus carpio Linn) selama pengangkutan sistem tertutup

$\mathrm{H}_{\mathrm{a}}$ : Ada pengaruh pemberian HP terhadap kelulusan hidup benih ikan mas (Cyprinus carpio Linn) selama pengangkutan sistem tertutup

\subsection{Metode Penelitian}

Metode penelitian yang digunakan adalah metode percobaan, dengan menguji secara langsung perlakuan pemberian hidrogen peroksida terhadap kelulusan hidup benih ikan mas.

\subsubsection{Rancangan Percobaan}

Penelitian ini menggunakan Rancangan Acak Lengkap (RAL) pola Non Faktorial karena memakai 1 faktor perlakuan dan nilainya berubah-ubah yaitu :

Perlakuan dalam penelitian ini adalah menggunkan kontrol dan dosis HP yang terdiri dari 3 taraf perlakuan yaitu :

1. $A=0$ miligram/liter

2. $B=0,1$ miligram/liter

3. $\mathrm{C}=0,2 \mathrm{miligram} / \mathrm{liter}$

4. $\mathrm{D}=0,3 \mathrm{miligram} / \mathrm{liter}$

Pada masing-masing perlakuan dan kontrol akan mendapatkan ulangan sebanyak 3 (tiga) kali. Sehingga diperlukan wadah percobaan sebanyak 12 wadah, yang penempatannya dilakukan secara acak terhadap semua wadah pengamatan (Lampiran 1).

Mengingat banyaknya faktor yang dapat mempengaruhi kelulusan hidup benih ikan mas, maka dalam percobaan ini dibuat beberapa asumsi, yaitu :

1. Kualitas benih ikan mas pada setiap wadah perlakuan adalah sama 
2. Kondisi lingkungan di sekitar wadah percobaan sama

3. Ketelitian selama penanganan benih ikan mas pada masing-masing wadah perlakuan adalah sama

\subsubsection{Prosedur Penelitian}

1. Wadah-wadah dan peralatan terlebih dahulu dibersihkan sehari sebelum penelitian, setelah itu air tawar yang berasal dari sumur bor sudah diendapkan selama dua hari sebelum penelitian.

2. Semua benih ikan mas diberok terlebih dahulu, yaitu dengan menempatkan benih ikan mas dalam bak pemberokan dan tidak diberi makan selama 2 hari.

3. Kantong plastik yang digunakan sebagai wadah uji dipersiapkan lapis dua. Masukkan air media dalam kantong plastik masing-masing 1 liter air/kantong.

4. Selanjutnya ke dalam setiap kantong plastik dimasukkan hidrogen peroksida dengan dosis masing-masing perlakuan yang ditentukan $(0 \mathrm{ml}, 0,1 \mathrm{ml}, 0,2 \mathrm{ml}$ dan $0,3 \mathrm{ml})$, setelah itu diaduk supaya tercampur atau larut dengan rata.

5. Kemudian masukkan benih ikan mas ke dalam kantong plastik yang telah diberi hidrogen peroksida, yaitu 20 ekor per wadah.

6. Kemudian kantong plastik diikat kencang dengan menggunakan karet gelang.

7. Masing-masing kantong plastik dimasukkan ke dalam kendaraan roda empat, dan siap untuk melakukan pengangkutan. Pengangkutan dilakukan selama 5 jam dari Medan Desa Tanah Jawa Pematang Siantar.

8. Melakukan pengukuran parameter kualitas air dilakukan sebelum dan setelah pengangkutan. Parameter yang diukur adalah suhu air, $\mathrm{pH}$ air dan oksigen terlarut air (DO).

9. Penghitungan jumlah benih ikan mas yang hidup dengan cara populasi awal sebanyak 20 ekor dikurangi jumlah benih ikan mas yang mati.

\subsection{Pengumpulan Data}

Data yang dikumpulkan meliputi kelulusan hidup yaitu dengan menghitung benih ikan mas yang masih hidup. Hasil penghitungan jumlah benih ikan mas dijadikan sebagai data hasil pengamatan yang kemudian diolah dengan cara mentabulasikannya terlebih dahulu, kemudian mengkonversikannya ke dalam bentuk persentase. Kelulusan hidup (Survival Rate) dihitung dengan memakai rumus sebagai berikut [3] :

$$
S R=\frac{N t}{N o} x 100 \%
$$

dimana : SR = Survival Rate (\%)

$$
\text { No }=\text { Populasi awal (ekor) }
$$

$\mathrm{Nt}=$ Populasi akhir (ekor)

Selanjutnya data hasil pengamatan tersebut dimasukkan ke dalam tabel simpul hasil perhitungan kelulusan hidup benih ikan mas. Selain kelulusan hidup data yang dikumpulkan adalah parameter kualitas air meliputi : suhu, pH dan DO.

\subsection{Analisis Data}

\subsubsection{Validasi Data}


Analisis data hasil pengamaatan dilakukan dengan Analisis Variansi (ANAVA) dan memenuhi syarat-syarat yang digunakan maka dilakukan uji homogenita ragam galat dan mengunakan sebaran chi-kuadrat dengan rumus sebagai berikut:

$X^{2}$ empirik $=2,3036\left\{\Sigma\left(r_{i}-1\right) \cdot \log S^{2}-\Sigma\left(r_{i}-1\right) \cdot \log S_{i}^{2}\right\}$

$\mathrm{X}^{2}$ murni $=\left(\frac{1}{c}\right) \cdot \mathrm{X}^{2}$ empirik

\subsubsection{Analisis Variansi}

Analisis variansi dilakukan berdasarkan rancangan percobaan acak kelompok dengan model linier bersifat additif sebagai berikut :

$$
\mathbf{Y}_{\mathrm{ij}}=\mu+\tau_{1}+\varepsilon_{\mathrm{ij}}
$$

Dimana :

$\mathrm{Y}_{\mathrm{ij}}=$ Total nilai pengamatan imotilisasi ikan mas ke $1,2, \ldots 12$ yang dikenai perlakuan tidak doberi deterjen kontrol, $0,5 \%, 1 \%, 1,5 \%, 2 \%$;

$\mu \quad=$ Nilai rata-rata dari total jumlah nilai pengamatan imotilisasi ikan mas

$\tau_{1}=$ Nilai pengamatan kelulusan hidup bemih ikan mas yang disebabkan pengaruh pemberian air limbah deterjen terhadap kelulusan hidup benih ikan mas (Cyprinus carpio Linn) $\varepsilon_{\mathrm{ij}}=$ Nilai eror percobaan dalam unit percobaan yang disebabkan oleh faktor nonperlakuan yang timbul pada unit-unit percobaan ke $1,2, \ldots 12$ yang dikenai perlakuan pemberian air limbah deterjen terhadap kelulusan hidup benih ikan mas (Cyprinus carpio Linn)

\section{Hasil dan Pembahasan}

\subsection{Kelulusan Hidup}

Berdasarkan hasil percobaan yang telah dilakukan terhadap kelulusan hidup benih ikan mas dari masing-masing perlakuan dosis Hidrogen Peroksida yang dicobakan diperoleh data hasil pengamatan rata-rata persentase kelulusan hidup benih ikan mas seperti pada gambar grafik histogrm di bawah ini.

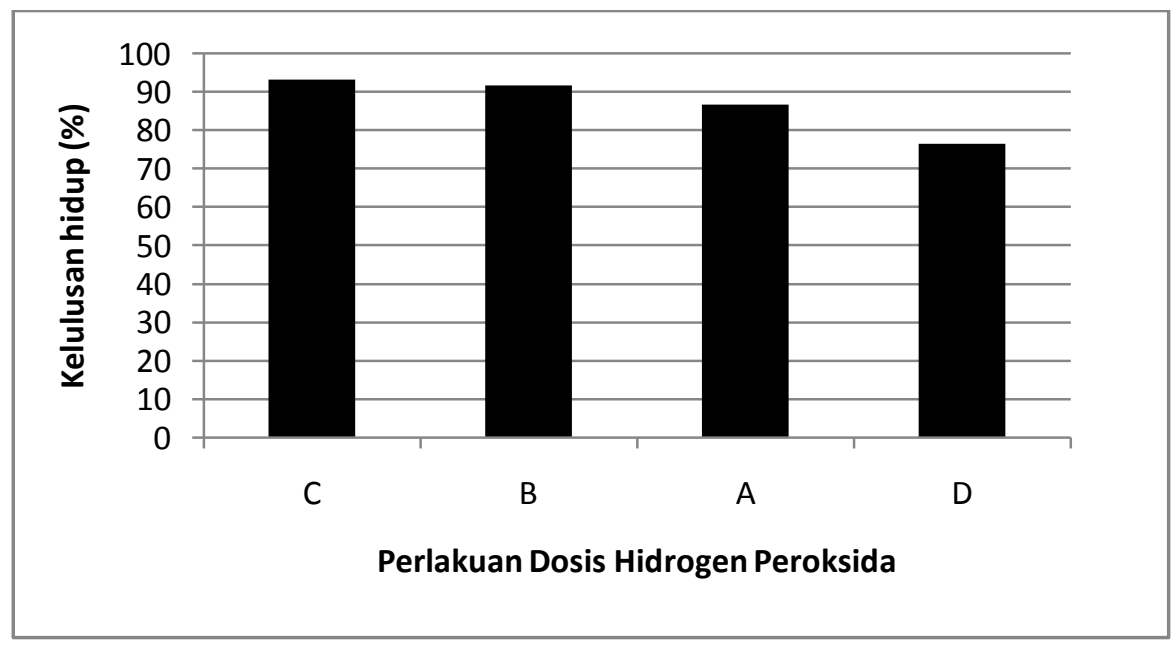

Gambar 1. Diagram Kelulusan Hidup Benih Ikan Mas 
Berdasarkan hasil pengmatan maka Perlakuan $\mathrm{C}$ merupakan perlakuan yang mempunyai angka kelulusan hidup tertinggi sebesar $93,33 \%$, diikuti perlakuan $B(91,66 \%), A$ $(86,66 \%)$, dan perlakuan D $(76,66 \%)$. Kelulusan hidup tertinggi pada perlakuan $\mathrm{C}$ sebesar $93,33 \%$ dan B $(91,66 \%)$ diduga disebabkan karena benih ikan mas memiliki ketahanan tubuh tertentu terhadap besarnya jumlah pemberian dosis HP menurut keadaannya masing-masing. Pemberian senyawa kimia baik untuk obat pembius (penenng) dengan dosis tepat dalam pengangkutan akan sangat menguntungkan, bahkan dapat ditingkatkan kepadatannya dua hingga tiga kali lipat dari berat ikan per satuan volume jika dosis yang digunakan tepat, karena laju konsumsi oksigen berkurang dan gerakan ikan menjadi lambat sebagai akibat resiko ikan terluka selama pengangkutan.

Angka kematian ikan uji dapat juga dilihat pada perlakuan yang tidak diberi HP (kontrol), hal ini disebabkan oleh pergerakan ikan yang tanpa obat penenang (pembius) lebih banyak, laju metabolisme ikan meningkat sehingga konsumsi $\mathrm{O}_{2}$ meningkat, ekskresi semakin banyak ditandai dengan banyaknya feces. Berdasarkan hasil penelitian [4] pada konsentrasi $\mathrm{H}_{2} \mathrm{O}_{2}$ air tawar berkisar antara 0,001 hingga 0,109 mg/L; sedangkan air laut berkisar 0,001 sampai $0,0136 \mathrm{mg} / \mathrm{L}$. Semakin tinggi dosis HP yang diberikan dalam pengangkutan akan mengakibatkan kelulusan hidup benih ikan mas rendah. HP digunakan untuk mengatasi infeksi jamur pada telur ikan, serta mengontrol bakteri dan parasit pada ikan budidaya. Hidrogen peroksida di alam ditemukan pada hampir seluruh permukaan air yang terpapar sinar ultraviolet dalam bentuk Dissolved Organic Carbon (DOC). Semakin tinggi konsentrasi $\mathrm{H}_{2} \mathrm{O}_{2}$ menunjukkan semakin tingginya kandungan DOC pada permukaan air[6].

\subsection{Kualitas Air}

Data pengukuran, suhu, Disolved Oxygen (DO) dan $\mathrm{pH}$ selama pelaksanaan penelitian dapat dilihat pada Tabel di bawah ini.

Tabel 1. Kisaran Nilai Rerata Suhu, DO dan pH Selama Penelitian

\begin{tabular}{ccccccc}
\hline \multirow{2}{*}{ Perlakuan } & \multicolumn{6}{c}{ Parameter Kualitas Air } \\
\cline { 2 - 7 } & \multicolumn{2}{c}{ Suhu } & \multicolumn{2}{c}{ DO } & \multicolumn{2}{c}{$\mathrm{pH}$} \\
\cline { 2 - 7 } & Sebelum & Sesudah & Sebelum & Sesudah & Sebelum & Sesudah \\
\hline A & $29^{\circ} \mathrm{C}$ & $31^{\circ} \mathrm{C}$ & $5,0 \mathrm{ppm}$ & $5,4 \mathrm{ppm}$ & 7,8 & 7,6 \\
$\mathrm{~B}$ & $29^{\circ} \mathrm{C}$ & $30^{\circ} \mathrm{C}$ & $5,0 \mathrm{ppm}$ & $5,6 \mathrm{ppm}$ & 7,8 & 7,8 \\
$\mathrm{C}$ & $29^{\circ} \mathrm{C}$ & $30^{\circ} \mathrm{C}$ & $5,0 \mathrm{ppm}$ & $5,6 \mathrm{ppm}$ & 7,8 & 7,8 \\
$\mathrm{D}$ & $29^{\circ} \mathrm{C}$ & $30^{\circ} \mathrm{C}$ & $5,0 \mathrm{ppm}$ & $55 \mathrm{ppm}$ & 7,8 & 7,8 \\
\hline
\end{tabular}

Sumber: Data Penelitian (2019).

Suhu dalam wadah sebelum penelitian diatur berada pada kisaran $29^{\circ} \mathrm{C}$, namun setelah masa pengangkutan berkisar antara $30-31^{\circ} \mathrm{C}$. Suhu adalah faktor penting yang dapat mempengaruhi metabolisme ikan. Suhu air memiliki pengaruh yang dominan terhadap kelangsungan kehidupan ikan. Suhu air yang optimal untuk budidaya ikan adalah $25-30^{\circ} \mathrm{C}[6]$. Nilai derajat keasaman air $(\mathrm{pH})$ sebelum pengemasan berkisar 7,8 dan setelah masa pengangkutan berkisar 7,6 pada perlakuan $A$ sedangkan pada perlakuan $B, C$, dan $D(7,8)$. Nilai $\mathrm{pH}$ setelah pengemasan mengalami penurunan dibanding sebelum dikemas. Hal ini diduga karena terdapatnya gas karbondioksida $\left(\mathrm{CO}_{2}\right)$ yang bereaksi dengan air membentuk asam karbonat $\left(\mathrm{H}_{2} \mathrm{CO}_{3}\right)$ yang dihasilkan oleh ikan melalui proses respirasi. Nilai $\mathrm{pH}$ air yang 
terukur sebesar 7,65 masih sesuai dengan kelayakan budidaya ikan yaitu 7,6-8,2 atau dengan nilai fluktuasi tidak lebih dari 1,3 [7]. Pada $\mathrm{pH}$ di bawah 5 dan di atas 9 tingkat kematian ikan menjadi lebih tinggi [5]. Pada DO sebelum dan sesudah penelitian terjadi perubahan, dimana sebelumnya nilai DO (5 ppm) dan sesudahnya berkisar $(5,4-5,6)$. Radikal bebas juga bisa berasal dari konsumsi oksigen, 2-3\% oksigen yang dikonsumsi akan dikonversi menjadi oksigen radikal (O) dan $\mathrm{H}_{2} \mathrm{O}_{2}$ dan peningkatan konsumsi oksigen pada jaringan akan menghasilkan reactive oxigenspecies (ROS) pada mitokondria, demikan juga dengan peningkatan suhu akan menghasilkan ROS yang akan menyebabkan kerusakan oksidatif [5]. Reaksi hidrogen peroksida dan air akan menghasilkan oksigen yang dapat dimanfaatkan oleh ikan pada media air, reaksinya adalah sebagai berikut: $5 \mathrm{H}_{2} \mathrm{O}_{2}+\mathrm{H}_{2} \mathrm{O} \rightarrow 5 \mathrm{H}_{2} \mathrm{O}+2 \mathrm{O}_{2}+\mathrm{Kalor}$ (kkal). Namun penurunan $\mathrm{pH}$ tersebut relatif kecil, dan masih dalam kisaran aman. Secara umum penambahan hidrogen peroksida tidak menyebabkan perubahan kualitas air (suhu, $\mathrm{pH}$, amonia, dan CO2), kecuali untuk kadar oksigen [8]

\section{Kesimpulan dan Saran}

Pemberian dosis HP harus tepat untuk mendapatkan derajat kelulusan hidup ikan mas yang tinggi yakni pada Perlakuan $\mathrm{C}$ sebesar $0,2 \mathrm{mg} /$ liter. Hal ini diduga karena mampu memperbaiki kualitas air terutama menaikan DO dari 5,0 menjadi 5,6 ppm dan mampu mempertahankan $\mathrm{pH}$ air tetap stabil berkisar 7,8. Mengingat $\mathrm{DO}$ dan $\mathrm{pH}$ sebagai faktor pembatas yang menentukan kelulusan hidup ikan mas selama masa pengangkutan.

\section{Daftar Pustaka}

[1] Pedersen, L.F., Per, B.P., Jeppe, L.N., Per, H.N. 2009. Peracetic acid degradation and effects on nitrification in recirculating aquaculture systems. Aquaculture. 296: 246-254, 2009.

[2] Taylor, J.J., Southgate, P.C., and Rose, R.A. 1997. Fouling Animals and Their Effect on The Growth of Silver-lip Pearl Oyster in Suspend Aquaculture. Aquaculture. 153: 31-40, 1997.

[3] Darmono, 1991. Budidaya Udang Penaeus. Kanisius, Jakarta. 104 hal.

[4] S. Andriyanto, Uni Purwaningsih, Shofihar Sinansari, dan Yohanna Retnaning Widyastuti. Efektivitas Hidrogen Peroksida Dalam Pengendalian Infeksi Ektoparasit Pada Ikan Lele Clarias gariepinus. Media Akuakultur, 13 (1): 49 57, 2018.

[5] Abele D, Burlando B, Viarengo A, and Portner HO. Exposure to elevated temperatures and hydrogen peroxide elicits oxidative stress and antioxidant renponse in the Antarctic intertidal limpet Nucella concinna. Comp BiochemPhysiol Part B 120 : 425 - 435, 1998.

[6] Hudin, J. M., Desi Susilwati, dan Muhammad Alfi Faizal. Implementasi Model Agile Pada Monitoring Suhu Kolam Ikan Dengan Algoritma Fuzzy Logic Berbasis Internet Of Thing (IOT).Jurnal Swabumi, Vol.6 No.1: 128-138, 2018

[7] Nurjanah, Komari dan E Susanto. Penambahan Hidrogen Peroksida $\left(\mathrm{H}_{2} \mathrm{O}_{2}\right)$ Dalam Mempertahankan Waktu Hidup Ikan Kerapu Lumpur (Epinephelus suillus). Buletin Teknologi Hasil Perikanan, Vol IX Nomor 2 : 13 - 21, 2006

[8] Khairuddin dan Munir. Studi Pengembangan Budidaya Ikan Sistem Kolam Air Deras Di Sungai Caramele Kota Parepare Sulawesi Selatan. Jurnal Galung Tropika, halaman 36-45, 2012. 